\title{
Quantitative transcript analysis of the inducible expression system pSIP: comparison of the overexpression of Lactobacillus spp. $\beta$-galactosidases in Lactobacillus plantarum
}

Tien-Thanh Nguyen ${ }^{1,4}$, Thu-Ha Nguyen², Thomas Maischberger², Philipp Schmelzer', Geir Mathiesen², Vincent GH Eijsink ${ }^{3}$, Dietmar Haltrich ${ }^{1}$ and Clemens K Peterbauer ${ }^{1 *}$

\begin{abstract}
Background: Two sets of overlapping genes, lacLMReu and laCLMAci, encoding heterodimeric $\beta$-galactosidases from Lactobacillus reuteri and Lactobacillus acidophilus, respectively, have previously been cloned and expressed using the pSIP vector system and Lactobacillus plantarum WCSF1 as host. Despite the high similarity between these lacLM genes and the use of identical cloning and expression strategies, strains harboring lacLMReu produced about twenty-fold more $\beta$-galactosidase than strains containing lacLMAci.

Results: In this study, the plasmid copy numbers (PCN) of expression vectors pEH9R (lacLMReu) and pEH9A (IacLMAci) as well as the transcription levels of both lacLM genes were compared using quantitative PCR methods. Analyses of parallel fermentations of $L$. plantarum harboring either pEH9R or pEH9A showed that the expression plasmids were present in similar copy numbers. However, transcript levels of lacLM from L. reuteri (pEH9R) were up to 18 times higher than those of lacLM from L. acidophilus (pEH9A). As a control, it was shown that the expression levels of regulatory genes involved in pheromone-induced promoter activation were similar in both strains.

Conclusion: The use of identical expression strategies for highly similar genes led to very different mRNA levels. The data indicate that this difference is primarily caused by translational effects that are likely to affect both mRNA synthesis rates and mRNA stability. These translational effects thus seem to be a dominant determinant for the success of gene expression efforts in lactobacilli.
\end{abstract}

\section{Background}

Lactic acid bacteria (LAB) are important micro-organisms in the food and beverages industry. Over the past few decades, LAB have been used not only as starter culture but also as producers of flavoring enzymes, antimicrobial peptides or metabolites that contribute to the flavor, texture and safety of food products [1-3]. Moreover, because of their food-grade status and probiotic characteristics, several LAB, especially lactobacilli, are considered as safe and effective cell factories for foodapplication purposes [2,3]. As a consequence, a variety of constitutive or inducible gene expression and protein

\footnotetext{
* Correspondence: clemens.peterbauer@boku.ac.at

'Food Biotechnology Lab, Department of Food Sciences and Technology,

University of Natural Resources and Life Sciences Vienna, Austria

Full list of author information is available at the end of the article
}

targeting systems for LAB hosts have been developed, including sugar-inducible, thermo-inducible and $\mathrm{pH}$ dependent expression systems $[1,2,4]$.

Two well-known inducible expression systems for LAB exploit promoters from bacteriocin operons, the NIsin-Controlled Expression system (NICE) [5] and the pheromone-inducible system pSIP [6]. The NICE system exploits genes and promoters involved in the production of the antimicrobial peptide (lantibiotic) nisin in Lactococcus lactis and the inducing substance is nisin itself [5]. Similarly, the pSIP systems were developed based on promoters and regulatory genes involved in the production of the class II bacteriocins sakacin A [7] and sakacin $\mathrm{P}[8,9]$ in Lactobacillus sakei. In these LAB, bacteriocin production is regulated by a three-component system, consisting of a secreted peptide pheromone 
(IP) which interacts specifically with a cognate membrane-embedded histidine protein kinase (HPK). A response regulator ( $R R$ ) encoded in the same operon as IP and HPK is activated by the HPK, leading to induction of all the promoters of the bacteriocin operons [8]. The pSIP systems have been used to over-produce several enzymes such as $\beta$-glucuronidase and aminopeptidase $\mathrm{N}$ in several Lactobacillus hosts $[6,10,11]$.

$\beta$-Galactosidases (lactase, EC 3.2.1.23) are known as important enzymes in the dairy industry [12-14]. The ability of $\beta$-galactosidases to convert lactose into galactose and glucose is used to prevent the crystallization of lactose, to improve sweetness, to increase the solubility of milk products, and to produce lactose-free food products [15]. Another beneficial ability of $\beta$-galactosidases is the trans-galactosylation reaction which co-occurs during lactose hydrolysis [12] and results in the formation of galacto-oligosaccharides (GOS). Similar to fructo-oligosaccharides (FOS), GOS possess prebiotic properties $[13,14,16,17]$.

Many $\beta$-galactosidases of lactobacilli, including the enzymes from $L$. reuteri and $L$. acidophilus, consist of two subunits, one large and one small, which are encoded by two overlapping genes, lacL and $l a c M$, respectively [13]. In a previous study, we have overexpressed the $\beta$-galactosidases from $L$. reuteri L103 and $L$. acidophilus R22 by cloning the lacLM genes into pSIP vectors [10]. Two of the resulting expression vectors, pEH9R and pEH9A, are based on pSIP409 and contain lacLMReu from L. reuteri L103 and lacLMAci from $L$. acidophilus R22, respectively [10]. The lacLM genes are under the control of the strong pheromone-inducible promoter $\mathrm{P}_{\mathrm{sppQ}}[6,11,18]$, to which they are translationally fused, and over-expression of these $\beta$-galactosidases in the well-studied food-grade strain Lactobacillus plantarum WCFS1 was successful. However, even though the amino acid sequences of these $\beta$-galactosidases are highly similar, both SDS-PAGE analyses of cell extracts and activity measurements showed that the two enzymes had very different production levels under identical conditions, with lacLMReu being expressed about twenty times more efficiently than lacLMAci [10].

The observed expression levels are the end product of transcription, translation and post-translational processes, which all may be influenced by a large number of factors, including the gene dose, which is determined by the plasmid copy number (PCN), and messengerRNA (mRNA) levels. In the present study we have used RT-qPCR to verify whether the different expression efficiencies of lacLMAci and lacLMReu correlate with differences in mRNA levels. Furthermore, we used RTPCR to determine the plasmid copy numbers of pEH9A and pEH9R. Since identical cloning strategies had been used for highly similar genes, substantial differences were not a priori expected. Interestingly, however, large differences in mRNA levels were found.

\section{Materials and methods \\ Bacterial strains and media}

Lactobacillus plantarum WCFS1 [19], harboring pEH9R or pEH9A containing the overlapping genes (lacLM) encoding $\beta$-galactosidase of Lactobacillus reuteri L103 and Lactobacillus acidophilus R22, were maintained in MRS (Merck, Darmstadt, Germany) containing $5 \mu \mathrm{g} / \mathrm{ml}$ erythromycin and $15 \%$ glycerol at $-70^{\circ} \mathrm{C}$.

\section{Fermentations}

Strains were activated from frozen stock in $5 \mathrm{ml}$ of MRS with $5 \mu \mathrm{g} / \mathrm{ml}$ erythromycin at $37^{\circ} \mathrm{C}$ for $16-18 \mathrm{~h}$. These cultures were used to inoculate $400 \mathrm{ml}$ MRS medium (40 $\mathrm{g} / \mathrm{l}$ glucose, $5 \mu \mathrm{g} / \mathrm{ml}$ erythromycin). Cultivations were done in an HT-Multifors system (Infors HT, Switzerland) with $\mathrm{pH}$ control at $\mathrm{pH} 6.5$, at $37^{\circ} \mathrm{C}$. Sodium hydroxide was used for maintaining the $\mathrm{pH}$. A low agitation speed (200 rpm) was set to ensure the homogeneity of medium and other parameters and to ensure continuous contact between bacterial cells and nutrient. Induction of gene expression was achieved by adding a 19-amino acid synthetic peptide pheromone, IP673, with a sequence identical to the sequence of the pheromone as originally isolated from Lactobacillus sakei LTH673 [20].

Growth of bacteria was monitored via the optical density at $600 \mathrm{~nm}\left(\mathrm{OD}_{600}\right)$. After six hours, when $\mathrm{OD}_{600}$ had reached around 3.0, IP673 was added to a final concentration of $80 \mathrm{ng} / \mathrm{ml}$ to induce lacLM gene transcription. Samples were collected at intervals for $\mathrm{OD}_{600}$ measurements, enzyme assays, and DNA and RNA isolation.

For $\beta$-galactosidase measurements, cells from $1 \mathrm{ml}$ of fermentation broth were pelleted by centrifugation at $13200 \mathrm{rpm}$ for $3 \mathrm{~min}$. Cells were re-suspended in buffer $\mathrm{P}$ [16], then disrupted by sonication $(4 \times 1 \mathrm{~min}$ at $100 \%$ power, interrupted by 1 min breaks and constant cooling on ice, using a Bandelin Sonopuls HD60, Berlin, Germany). Subsequently, cell debris was removed by centrifugation at $13200 \mathrm{rpm}$ for $10 \mathrm{~min}$ at $4^{\circ} \mathrm{C}$. The obtained crude extract was used for measuring $\beta$-galactosidase activity as well as protein concentration. For DNA or RNA isolation, cells were pelleted as described, shock-frozen by liquid nitrogen and stored at $-80^{\circ} \mathrm{C}$ until further use.

\section{Enzyme assays}

$\beta$-Galactosidase activity was determined using $o$-nitrophenyl- $\beta$-D-galactopyranoside (oNPG) as previously described [13]. Protein concentration was determined using the method of Bradford [21] with bovine serum albumin as standard. 


\section{Bacterial DNA isolation and purification for PCN estimation}

A sample $(1 \mathrm{ml})$ of the culture at an $\mathrm{OD}_{600}$ of 10 was used for DNA isolation. For cells harvested at lower values of $\mathrm{OD}_{600}$, correspondingly higher culture volumes were collected (e.g., $2 \mathrm{ml}$ of a culture with an $\mathrm{OD}_{600}$ of $5)$. DNA was isolated and purified using the phenolchloroform extraction method as described in literature [22]. The purified bacterial DNA was stored at $-20^{\circ} \mathrm{C}$ until use.

\section{RNA isolation and purification}

Total RNA was isolated using the peqGOLD Bacterial kit (Peqlab, Biotechnologie GmbH, Germany) according to the supplier's instructions without DNA on-column digestion. The concentration of total RNA was determined spectrophotometrically at $260 \mathrm{~nm}\left(\mathrm{~A}_{260}\right)$ (Beckman DU80). RNA integrity was examined by denaturing agarose gel electrophoresis ( $2 \%$ agarose, $2.2 \mathrm{M}$ formaldehyde). DNA contaminations in total RNA samples were completely removed by digestion with $1 \mathrm{U} / \mu \mathrm{l}$ of DNAse (PeqLab) in a total volume of $20 \mu \mathrm{l}$ using DNAse reaction buffer as recommended [23]. After $10 \mathrm{~min}$ at $37^{\circ} \mathrm{C}$, $30 \mathrm{mM}$ EDTA solution was added to a final concentration of $3 \mathrm{mM}$. The mixture was heated at $70^{\circ} \mathrm{C}$ for 15 min to inactivate DNAse and stored at $-70^{\circ} \mathrm{C}$. The absence of residual DNA contamination was confirmed by normal PCR with $16 \mathrm{~S}$ primer pair (not shown).

\section{Reverse transcription and real time quantitative PCR Reverse transcription}

RNA was reverse-transcribed using the First Strand cDNA Synthesis kit (Fermentas, St. Leon-Roth, Germany) with random hexamer priming and 100 units of reverse transcriptase (RevertAidTM M-MuLV Reverse Transcriptase, Fermentas). The resulting cDNAs were stored at $-20^{\circ} \mathrm{C}$. For control samples, dimethylpyrocarbonate (DEPC) treated water was used to replace reverse transcriptase.

\section{Oligonucleotide primers}

Oligonucleotide primers used in this study are listed in Table 1 . For plasmid copy number estimation, the erythromycin resistance gene $\operatorname{ermB}$ and $16 \operatorname{SrRNA}$ were chosen as representatives for plasmid DNA and genomic DNA, respectively. From the sequences of these genes, two primer pairs called Ery ${ }^{\mathrm{R}}$ and $16 \mathrm{~S}$ were designed (Table 1).

For relative mRNA quantification of the three genes lacLMReu, lacLMAci and $\operatorname{sppKR}, 3$ primer pairs called LacReu, LacAci and SppKR, respectively, were designed. The two former primer pairs were designed so that their characteristics as well as the length of amplicons were similar. The chromosomal16SrRNA gene was used as reference gene.

\section{$R T-P C R$ reaction using SYBR Green I dye}

The thermal cycling system iCycler and myIQ single Color Real-Time PCR Detection system (BioRad, Hercules, CA) were used for qPCR amplification and detection. The qPCR reactions ( $25 \mu$ l total volume) were prepared in duplicates in 96-wells plates (BioRad) that were sealed with optical adhesive covers (Microseal 'B' film, BioRad). Each reaction included an optimized concentration for each of forward and reverse primers (see Table 1), $12.5 \mu \mathrm{l}$ of Perfecta SYBR Green Super mix of IQ (Quanta Biosciences), and $2.5 \mu \mathrm{l}$ of DNA template. Negative controls (no template control), prepared by replacing the DNA template with DEPC water, were included in each run to confirm the absence of DNA

Table 1 Oligonucleotide primers used in this study

\begin{tabular}{|c|c|c|c|c|c|}
\hline Primer & Sequence $5^{\prime}-3^{\prime a}$ & $\mathrm{~T}_{\mathrm{a}}^{\mathrm{b}}\left({ }^{\circ} \mathrm{C}\right)$ & Concentration $^{c}(\mathrm{nM})$ & Product size (bp) & Tm product $\left({ }^{\circ} \mathrm{C}\right)$ \\
\hline $16 S_{-} f$ & TGATCCTGGCTCAGGACGAA & 60 & 250 & 81 & 81 \\
\hline $16 S_{-} r$ & TGCAAGCACCAATCAATACCA & & 250 & & \\
\hline Ery $_{-}^{R} f$ & CCGTGCGTCTGACATCTAT & 60 & 250 & 108 & 79 \\
\hline Ery $_{-}^{R}{ }_{r}$ & TGCTGAATCGAGACTTGAGTG & & 250 & & \\
\hline LacReu_f & CCA GAT TCC GTG GTA TTA CCT TTG TG & 60 & 250 & 154 & 80 \\
\hline LacReu_r & TAC TACT ACG TCA CGC CAT TGA GGA AC & & 500 & & \\
\hline LacAci_f & TCTAGTTCACTACGAAGGTGTCG & 60 & 500 & 154 & 76.5 \\
\hline LacAci_r & GTCATGCATGTATTCACACTCC & & 500 & & \\
\hline SppKR_f & CAAGCCGTTCAAGAAACCGAT & 60 & 250 & 144 & 78.5 \\
\hline SppKR_r & AGCGCCTITCGTTGAATAGCC & & 500 & & \\
\hline $11 \mathrm{n} 15 \_f$ & GATGACCCGGAAATTITICGCGTCAATCAAT & CCAGC & & & \\
\hline $11 n 15 \_r$ & GACGCGAAAAATTTCCGGGTCATC & & & & \\
\hline
\end{tabular}


contaminations in the reagents. Before setting up the experiments described in the Results section, primer concentrations, annealing temperatures and DNA template concentrations were optimized according to procedures and criteria described in [23], and the final optimized reaction parameters are shown in Table 1.

The qPCR reactions were conducted as follows: initial denaturation at $95^{\circ} \mathrm{C}$ for 3 min followed by 50 cycles of $20 \mathrm{~s}$ at $95^{\circ} \mathrm{C}, 20 \mathrm{~s}$ at $60^{\circ} \mathrm{C}$, and $72^{\circ} \mathrm{C}$ for $10 \mathrm{~s}$. The fluorescence signal was collected at the end of each extension step at $72^{\circ} \mathrm{C}$. Afterwards, the temperature was increased from $55^{\circ} \mathrm{C}$ to $95^{\circ} \mathrm{C}$ at a rate of $0.2^{\circ} \mathrm{C} / \mathrm{s}$ to establish the melting curve.

The threshold cycle values $\left(C_{t}\right)$ were automatically determined by the software Biorad MyIQ optical system Version 2.0.

\section{Calculation of the PCN value}

Based on the PCN definition, which is the number of copies of a plasmid present per chromosome in bacteria $[24,25]$, the PCN can be calculated by the following equation [26]: $P C N=\frac{E_{c}^{C_{c}}}{E_{p} C_{p p}}(1)$, here, $E_{c}, C_{t c}$ and $E_{p}, C_{t p}$ are the amplification efficiency and the threshold cycle value of the amplicon representing chromosome and plasmid, respectively. The equivalence between the amplification efficiency (E) of plasmid and chromosome amplicons was confirmed in validation experiments as recommended [27]. In addition, to compare the PCN between two recombinants, the relative $\mathrm{PCN}$ values were calculated using the comparative $C_{t}$ method $\left(\Delta \Delta \mathrm{C}_{\mathrm{t}}\right)$, in the following equation: $\frac{p E H 9 R}{p E H 9 A}=2^{-\Delta \Delta C_{t}}$ (2), where $\Delta \Delta C_{t}=\Delta C_{t}$ of the sample corresponding to pEH9R $-\Delta C_{t}$ of sample corresponding to pEH9A, and $\Delta C_{t}=$ average $C_{t}$ value of target (for erythromycin resistance gene) - average $C_{t}$ value of reference gene.

\section{Calculation of the expression ratio}

The relative expression level between the two genes (e.g. $\mathrm{A}$ and $\mathrm{B}$ ) was also estimated as described in equation (2), where $\Delta \Delta \mathrm{C}_{\mathrm{t}}=\Delta \mathrm{C}_{\mathrm{t}}$ corresponding to gene A $-\Delta \mathrm{C}_{\mathrm{t}}$ corresponding to gene $\mathrm{B}$ and $\Delta \mathrm{C}_{\mathrm{t}}=$ average $\mathrm{C}_{\mathrm{t}}$ of target genes (A or $\mathrm{B})$ - average $\mathrm{C}_{\mathrm{t}}$ of reference gene $(16 \mathrm{~S}$ rRNA).

The relative expression level of each gene of interest compared to the time point before induction (here after $6 \mathrm{~h}$ of cultivation) was estimated accordingly, but $\Delta \Delta \mathrm{C}_{\mathrm{t}}$ $=\Delta \mathrm{C}_{\mathrm{t}}$ of genes of interest at different time points $-\Delta \mathrm{C}_{\mathrm{t}}$ of genes of interest after $6 \mathrm{~h}$ of cultivation. In the present work, the genes of interest were lacLMReu, lacL$M a c i$ and $s p p K R$.

\section{Codon usage and mRNA secondary structure analysis}

The codon usage of the lacLM genes was compared to those of $L$. plantarum WCFS1 using the Graphical Codon Usage Analyzer (http://gcua.schoedl.de/index. html). The codon usage table of L. plantarum WCFS1 is estimated based on 3057 CDS's (934462 codons) (http:// www.kazusa.or.jp/codon/cgi-bin/showcodon.cgi?species=220668). mRNA secondary structure for both genes was analyzed using mfold (http://mobyle.pasteur.fr/cgibin/portal.py?form=mfold) from the transcription start point (65 nt upstream of ATG) to $150 \mathrm{nt}$ (50 codons).

\section{Expression of a mutated variant of the $L$. acidophilus IacLM gene}

To exchange the triplets 11 and 15 of the L. acidophilus lacLM-coding region the overlapping primers $11 \mathrm{n} 15$ _f and $11 n 15 \_r$ (Table 1 ) were used. Site-directed mutagenesis PCR was performed in $25-\mu l$ reaction volume with Phusion High Fidelity DNA Polymerase (Finnzymes, Espoo, Finland) using pEH9A as the template (annealing temperature of $52^{\circ} \mathrm{C}$ ). The residual template after amplification was digested by $1 \mu \mathrm{l} D p n \mathrm{I}(20 \mathrm{U})$ (Fermentas) for $4 \mathrm{~h}$ at $37^{\circ} \mathrm{C}$. The reaction products were purified using the Wizard ${ }^{\circledR}$ SV Gel PCR Clean-Up system (Promega, Madison, WI) and transformed into $E$. coli NEB5 $\alpha$. Several randomly picked transformants appearing after $24 \mathrm{~h}$ incubation at $37^{\circ} \mathrm{C}$ were checked by sequencing of the isolated plasmids. A plasmid with verified mutations at triplets 11 and 15 and no additional changes was selected and named pEH9A1. To exclude possible undesired mutations in the (nonsequenced) plasmid backbone, the 3.3-kb SpeI-EcoRI fragment from pEH9A1 was ligated into a 5.2-kb SpeIEcoRI-fragment from pEH9A, resulting in the plasmid pEH9A2. This plasmid was electroporated into competent cells of L. plantarum WCFS1. L. plantarum WCFS1 harboring pEH9R, pEH9A2 and pEH9A were cultivated and induced in parallel in a Multifors fermenter as described above. Harvested cells were disrupted using 1 gram glass beads in a Precellys 24 bead mill (Peqlab). The cell-free extracts were obtained after a centrifugation step at $13200 \mathrm{rpm} / 10 \mathrm{~min}$ at $4^{\circ} \mathrm{C}$ and used for enzyme assays and protein analysis.

Experiments in this manuscript were conducted in accordance with the Austrian Gentechnikgesetz (GTG). No experiments requiring approval by an ethics commission are described in the manuscript.

\section{Results}

\section{Fermentations}

L. plantarum WCFS1 harboring either $\mathrm{pEH} 9 \mathrm{R}$ or pEH9A (carrying lacLMReu and lacLMAci, respectively, under the control of the $\mathrm{P}_{\mathrm{sppQ}}$ promoter) was cultivated in a $\mathrm{pH}$-controlled fermentor using conditions that had previously been determined to result in high enzyme yields (unpublished data). Gene expression was induced by adding the peptide pheromone IP- $6736 \mathrm{~h}$ after the start of the fermentation (at an $\mathrm{OD}_{600}$ of approximately 
3.0). Results presented in Figure 1 show that growth of the two strains was nearly identical over the entire fermentation. In contrast, $\beta$-galactosidase yields (in terms of both units per volume of fermentation broth and units per mg protein) were considerably different. $L$. plantarum WCFS1 carrying pEH9A showed a maximum activity around $0.8 \mathrm{U} / \mathrm{ml}$ and $2.5 \mathrm{U} / \mathrm{mg}$, whereas with pEH9R maximum activities reached about $22 \mathrm{U} / \mathrm{ml}$ and $62 \mathrm{U} / \mathrm{mg}$ (Figure 1). SDS-PAGE experiments confirmed that these differences are correlated with large differences in protein production levels, as was observed in earlier work with these constructs [10]. Previous studies have shown that the purified $\beta$-galactosidases from $L$. reuteri and $L$. acidophilus have similar specific activities $[13,16]$.

\section{Plasmid copy numbers}

Plasmid copy numbers (PCN) in cells harboring pEH9R or pEH9A were compared after $6 \mathrm{~h}$ (point of induction), $8 \mathrm{~h}, 12 \mathrm{~h}$ and $24 \mathrm{~h}$ of cultivation. PCN ratios for pEH9R versus $\mathrm{pEH} 9 \mathrm{~A}$ varied between 1.39 and 0.79 , i.e. close to one, in all cases (Table 2). Thus, both plasmids had similar copy numbers throughout the fermentation. The PCN for pEH9R in L. plantarum WCFS1 was determined to be approximately three to four.

\section{Transcription level of IacLM genes}

To study mRNA levels and the effect of induction on the expression of lacLM genes, the relative expression of lacLMReu and lacLMAci at several time points (2, 6 and $18 \mathrm{~h}$ after induction, i.e. 8,12 and $24 \mathrm{~h}$ after start of the fermentation) was compared to the expression of these genes just before induction (6 h after start of the

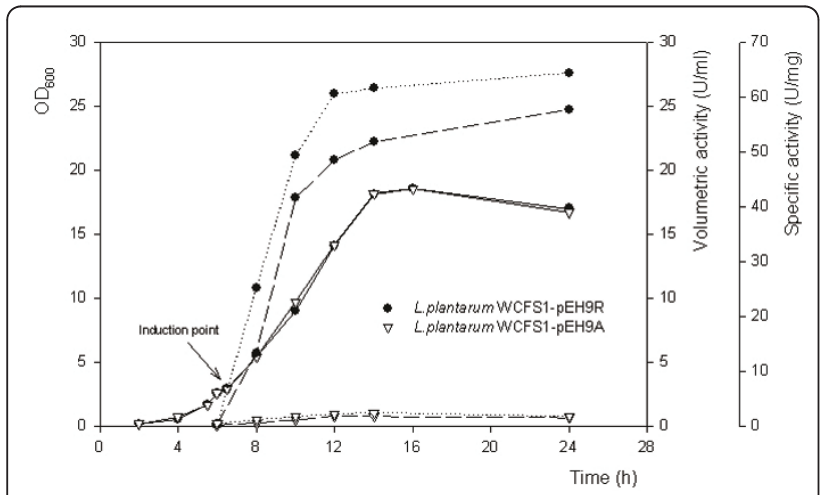

Figure 1 Time course for growth of L. plantarum WCFS1 carrying $\mathrm{pEH} 9 \mathrm{R}$ or $\mathrm{pEH} 9 \mathrm{~A}$. Cultivations were carried out with $\mathrm{pH}$ control at pH 6.5 in $400-\mathrm{ml}$ laboratory fermentors at $37^{\circ} \mathrm{C}$ using MRS medium (40 g/l glucose). The graph shows $\mathrm{OD}_{600}$ (solid lines), $\beta$ galactosidase activity (units per milliliter of fermentation broth) (dashed lines) and specific activity (units per milligram protein) (dotted lines). Cultures were induced with $80 \mathrm{ng} / \mathrm{ml}$ of pheromone after six hours of growth, i.e. at an $\mathrm{OD}_{600}$ of approximately 3.0. fermentation). Table 2 shows strongly increased expression of the lacLM genes 2 and $6 \mathrm{~h}$ after induction. Messenger-RNA levels for lacLMReu showed an approximately 60 -fold increase after $8 \mathrm{~h}(2 \mathrm{~h}$ after induction), whereas mRNA levels for lacLMAci were increased about 18 -fold at the same time point. Subsequently, mRNA levels decreased and they did so faster for lacLMAci than for lacLMReu. After $24 \mathrm{~h}$ of cultivation (18 h after induction) mRNA levels for lacLMReu were still considerably elevated, whereas mRNA levels for lacL$M A c i$ were lower than before induction (Table 2).

\section{Transcription levels of sppKR}

Addition of peptide pheromone to the growth medium will induce the expression of $\operatorname{spp} K$ and $\operatorname{spp} R$, and this autoinduction loop will increase the expression of lacLM. Although not likely, the strength of the expression of $\operatorname{sp} p K R$ may vary between the two plasmids. Therefore, we analyzed mRNA levels for $s p p K R$ in the two strains harboring pEH9R or pEH9A, before and after induction (Table 2). Expression of $s p p K R$ indeed increased after induction, albeit by not more than approximately a factor two (Table 2 ). The ratio between the $\operatorname{sp} K R$ transcript levels in the strains harboring pEH9R or pEH9A was close to 1 at all tested time points, showing that the expression levels of $\operatorname{spp} K R$ were essentially identical in both strains. For both fermentations (pEH9R and pEH9A), the transcript level of $s p p K R$ was compared to that of the reporter genes, lacLM. Before induction, the mRNA level of $\operatorname{spp} K R$ was higher than the level of lacLM mRNA (approximately five-fold and 14-fold for pEH9R and pEH9A, respectively). After induction these ratios decreased to about 0.15 for pEH9R and 2.0 - 2.4 for pEH9A (Table 3), reflecting the much higher mRNA levels for lacLMReu after induction.

\section{Codon usage analysis}

The mean difference of codon usage in the lacLM genes from $L$. reuteri and $L$. acidophilus compared to the codon usage of L. plantarum WCFS1 was $16.48 \%$ and $23.45 \%$ (for $l a c L$ ) and $18.22 \%$ and $25.75 \%$ (for $l a c M$ ), respectively. The total numbers of "rare codons" (i.e., codons used in less than $20 \%$ of the cases) and "very rare codons" (less than 10\%) are approximately equal in the lacLM genes from $L$. reuteri and $L$. acidophilus, but the latter shows a larger number of rare codons in the first 50 triplets of the L. acidophilus gene (seven, vs. four in the L. reuteri gene; see Figure 2).

\section{Expression of a mutated $L$. acidophilus lacLM gene}

In order to investigate the influence of the observed differences in codon usage on transcription and possibly translation we constructed a mutated variant of the $L$. 
Table $2 \beta$-Galactosidase activity and transcript levels

\begin{tabular}{|c|c|c|c|c|c|c|c|c|}
\hline \multirow{2}{*}{$\begin{array}{c}\text { Time } \\
\text { (h) }\end{array}$} & \multirow{2}{*}{$\begin{array}{c}\text { Time after } \\
\text { induction (h) }\end{array}$} & \multicolumn{3}{|c|}{ pEH9R } & \multirow{2}{*}{$\begin{array}{l}\text { PCN ratio pEH9R/ } \\
\text { pEH9A }\end{array}$} & \multicolumn{3}{|c|}{ pEH9A } \\
\hline & & $\underset{\mathrm{a}}{\text { Activity }}$ & $\begin{array}{c}\text { lacLM } \\
\text { expression level }\end{array}$ & $\begin{array}{c}\text { sppKR } \\
\text { expression level }\end{array}$ & & $\begin{array}{c}\text { Activity } \\
\mathrm{a}\end{array}$ & $\begin{array}{c}\text { lacLM } \\
\text { expression level }\end{array}$ & $\begin{array}{c}\text { sppKR } \\
\text { expression level }\end{array}$ \\
\hline $6^{b}$ & 0 & 1 & $1.00 \pm 0.07$ & $1.00 \pm 0.16$ & $1.39 \pm 0.25$ & 1 & $1.00 \pm 0.13$ & $1.00 \pm 0.21$ \\
\hline 8 & 2 & 56.1 & $59.9 \pm 15.6$ & $1.88 \pm 0.11$ & $0.81 \pm 0.07$ & 2.42 & $17.8 \pm 4.3$ & $2.49 \pm 0.04$ \\
\hline 12 & 6 & 135 & $55.4 \pm 13.5$ & $1.67 \pm 0.39$ & $0.79 \pm 0.01$ & 4.48 & $11.9 \pm 1.9$ & $2.00 \pm 0.20$ \\
\hline 24 & 18 & 144 & $16.4 \pm 2.6$ & - & $1.34 \pm 0.06$ & 3.56 & $0.46 \pm 0.12$ & - \\
\hline
\end{tabular}

Activity levels and transcript levels of lacLM and sppKR in strains harboring pEH9R or pEH9A are related to the respective values at the induction point (6 $\mathrm{h}$ into the cultivation)

The plasmid copy number (PCN) ratio is the value for the pEH9R-harboring strain divided by the value for the pEH9A-harboring strain

${ }^{\text {a }}$ Specific activity $(\mathrm{U} / \mathrm{mg}$ protein)

b Just before induction

acidophilus lacLM gene. Triplets in codon 11 (CCT, encoding proline) and 15 (AGA, encoding arginine) (Figure 2A), which are considered very rare in $L$. plantarum WCFS1, were replaced with the corresponding codons from the $L$. reuteri gene, which are more common in L. plantarum WCFS1 (CCG and CGC, respectively; Figure 2B). The mutated gene (on the vector pEH9A2) was expressed in L. plantarum WCFS1 under the same conditions as described for pEH9A and pEH9R, using bacteria harboring these two plasmids as control. Resulting $\beta$-galactosidase activities in the cultures harboring pEH9A2 were indeed higher than in those harboring pEH9A, but only by roughly $20-40 \%$ (Table 4).

\section{Discussion}

We have previously shown that lactobacillal lacLM genes can be overexpressed in Lactobacillus plantarum WCFS1 using the inducible pSIP expression system [10]. In this previous work we observed remarkably large differences in expression levels of $\beta$-galactosidases from different Lactobacillus strains. In the present study, we have used optimized conditions (unpublished observations) in parallel fermentations of $L$. plantarum WCFS1 expressing different lacLM genes. Under conditions of $\mathrm{pH}$ control ( $\mathrm{pH}$ 6.5) and high sugar content (see Materials and Methods section), the highest $\beta$-galactosidase

Table 3 Ratio of expression levels of sppKR versus IacLM in L. plantarum WCFS1 carrying PEH9R and L. plantarum WCFS1 carrying pEH9A

\begin{tabular}{cccc}
\hline Time $(h)$ & Time after induction $(h)$ & pEH9R & pEH9A \\
\hline $6^{\text {a }}$ & 0 & $4.87 \pm 0.78$ & $14.32 \pm 2.96$ \\
\hline 8 & 2 & $0.15 \pm 0.01$ & $2.01 \pm 0.03$ \\
\hline 12 & 6 & $0.15 \pm 0.03$ & $2.40 \pm 0.23$ \\
\hline
\end{tabular}

Values were obtained by dividing the average transcript number of $s p p K R$ with the average transcript number of lacLM as described in Material and Methods

a Just before induction activities were observed in the late exponential phase, where expression of lacLMReu yielded $65 \mathrm{U} / \mathrm{mg}$ protein compared to only $2.5 \mathrm{U} / \mathrm{mg}$ obtained with lacLMAci.

Plasmid copy numbers may have significant effects on the synthesis of recombinant proteins encoded by a plasmid-borne gene [25]. Plasmids pEH9R and pEH9A were both constructed using an identical pSIP409 backbone containing the 256rep replication determinant derived from the L. plantarum NC7 plasmid p256 [28]. Copy numbers of vectors with this origin of replication are rather low, and were determined to be approximately three in L. sakei Lb790 and six in L. plantarum NC8, using slot-blot hybridization [11,28]. In agreement with these reports, RT-PCR quantification yielded a copy number for pEH9R in L. plantarum WCFS1 of 3 to 4 . The ratio of the plasmid copy numbers in the pEH9R- and pEH9A-harboring strains of L. plantarum WCFS1 was close to one during the fermentation, meaning that the large differences in $\beta$-galactosidase production levels are not due to gene dose effects.

The pSIP409 vector system is based on quorum sensing, because induction by the peptide pheromone also induces transcription of the sppKR operon, via the inducible $\mathrm{P}_{\text {sppIP }}$ promoter $[6,29,30]$. From earlier studies it is known that the transcription levels of the two components of the regulatory system (histidine kinase and response regulator) influence the transcription of the reporter gene $[6,29,30]$. Studies with reporter genes have shown that the $\mathrm{P}_{\text {sppIP }}$ promoter differs from e.g. the $\mathrm{P}_{\mathrm{sppQ}}$ promoter in that it is more leaky, i.e. it displays more activity under non-inducing conditions [31]. This is supported by our comparative data on the transcription of $\operatorname{sp} K R$ and lacLM, showing that before induction the former operon has higher transcription levels (Table 3 ). Somewhat surprisingly, transcription of $\operatorname{spp} K R$ increased only approximately two-fold upon induction, compared to an up to 60 -fold increase for the lacLM genes controlled by $\mathrm{P}_{\mathrm{sppQ}}$ (in strains harboring $\mathrm{pEH} 9 \mathrm{R}$ ) (Table 2). The results of previous studies suggest that 


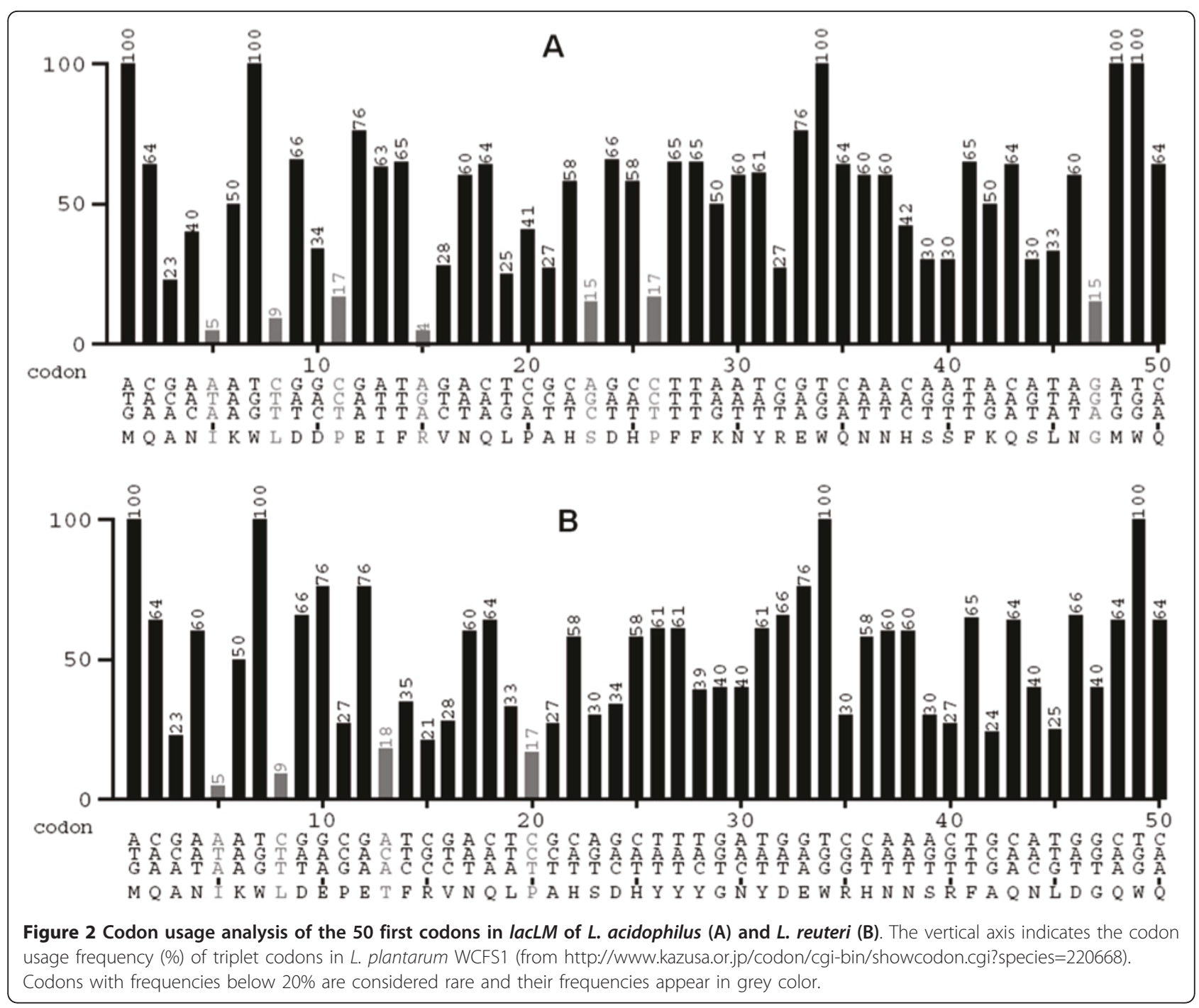

Table $4 \beta$-Galactosidase activity of $L$. plantarum WCFS1 harboring pEH9R, pEH9A and pEH9A2 ${ }^{\mathrm{a}}$

\begin{tabular}{|c|c|c|c|c|}
\hline \multicolumn{2}{|c|}{ Volumetric activity (kU/L) } & \multirow[b]{2}{*}{ WCFS1 + pEH9A } & \multirow[b]{2}{*}{ WCFS1 + pEH9R } & \multirow[b]{2}{*}{ Ratio (pEH9A2/pEH9A } \\
\hline Time (h) & WCFSI + pEH9A2 & & & \\
\hline 6 & $0.23 \pm 0.00$ & $0.17 \pm 0.00$ & $2.45 \pm 0.10$ & 1.43 \\
\hline 8 & $1.34 \pm 0.05$ & $1.09 \pm 0.08$ & $12.0 \pm 0.4$ & 1.23 \\
\hline 12 & $3.00 \pm 0.12$ & $2.40 \pm 0.19$ & $76.3 \pm 4.1$ & 1.25 \\
\hline 24 & $3.17 \pm 0.15$ & $2.69 \pm 0.31$ & $101 \pm 6$ & 1.19 \\
\hline
\end{tabular}

\begin{tabular}{ccccc}
\hline \multicolumn{2}{c}{ Specific activity $(\mathbf{U} / \mathbf{m g})$} & & & \\
\hline Time $(\mathrm{h})$ & WCFSI + pEH9A2 & WCFS1 + pEH9A & WCFS1 + pEH9R & Ratio (pEH9A2/pEH9A) \\
\hline 6 & $1.15 \pm 0.04$ & $0.85 \pm 0.08$ & $16.1 \pm 0.1$ & 1.36 \\
\hline 8 & $2.83 \pm 0.08$ & $2.60 \pm 0.07$ & $39.0 \pm 3.4$ & 1.09 \\
\hline 12 & $3.18 \pm 0.10$ & $2.67 \pm 0.13$ & $95.3 \pm 0.2$ & 1.19 \\
\hline 24 & $3.31 \pm 0.41$ & $2.85 \pm 0.33$ & $97.1 \pm 5.7$ & 1.16 \\
\hline
\end{tabular}

a The method used for cell disruption used in this study differed from the method used to produce Fig. 1 (see Materials and Methods). This explains why the absolute enzyme activity values vary between the two experiments. 
the $\operatorname{spp} K R$ transcript is unstable [8]. It is thus conceivable that transcription of these regulatory genes transiently increased to higher levels immediately after addition of the IP, and was already decreasing again two hours later, when the first samples were taken. This may also explain the discrepancy with the results of Risøen et al. [31], who found higher apparent degree of induction using reporter genes. Reporter protein activity can remain stable even after transcription of the encoding gene has ceased and the corresponding mRNA is already degraded and no longer detectable. For the purpose of this study, the most important conclusion is that transcription of $s p p K R$ in strains harboring either pEH9R or pEH9A is essentially equal, both before and after induction. Variations in the transcription levels of $s p p K R$ are therefore not responsible for the large differences in the production levels of the two $\beta$ galactosidases.

In previous studies of gene regulation in the natural sakacin $\mathrm{P}$ producer [8] transcripts for the operon under control of the $\mathrm{P}_{\text {sspQ }}$ promoter could be detected as early as 15 minutes after induction, and maximum levels were reached after 4 hours. Northern blots [8] showed that transcript levels were close to the maximum 2 to 4 hours after induction. In our study, maximum transcript levels for lacLM were observed two hours for both pEH9R and pEH9A (Table 2). The mRNA levels were slightly lower 6 hours after induction, i.e. at the start of the stationary phase. The highest activity of $\beta$-galactosidase was observed $6 \mathrm{~h}$ after induction $(12 \mathrm{~h}$ of cultivation), indicating an accumulation of the enzyme (Figure 1 ). After $24 \mathrm{~h}$ of cultivation, well into the stationary phase, mRNA of lacLMReu was still detected at an 18fold higher level than before induction (Table 2). In contrast, mRNA levels for lacLMAci were lower than before induction at this time point, indicating that lacLMReu mRNA is much more stable than lacLMAci mRNA in L. plantarum WCFS1.

The present data clearly show that the large differences in protein production observed for lacLMReu and lacLMAci correlate with different mRNA levels. It is unlikely that this is due to differences in the frequency or efficiency of transcription initiation, since the two constructs are identical up to their start codons. Incidental mutations in the two promoter sequences causing different transcriptional efficiency were ruled out by sequencing (data not shown). Thus, translational effects on mRNA production or stability must be the main cause of the large difference in mRNA levels, especially in light of the observed faster decrease in lacLMAci mRNA levels, indicating different mRNA stabilities. Translational effects on mRNA levels are often ascribed to the impact of translation on mRNA stability, the main idea being that naked untranslated mRNA is prone to degradation by ribonucleases. It should be noted though that low translation levels will also affect mRNA synthesis directly, either because longer stretches of nascent naked mRNA will be prone to premature Rho-mediated transcription termination [32,33] or because a lack of ribosomes promotes "back-tracking" of the RNA polymerase complex and thus delays transcription, as recently shown by Proshkin et al. [34].

One potential cause of variation in the amount of ribosomes on an emerging mRNA concerns variation in translation initiation frequencies due to variation in the sequence and accessibility of the ribosome-binding site (Shine-Dalgarno-sequence) [35,36]. For example, mRNAs with stable secondary structures near the translational start can hinder ribosome access to the translational initiation region (TIR) (= the ribosome binding site, the start codon and adjacent up- and downstream regions) $[37,38]$. Analyses using the mfold web server [39] showed only small differences between the two predicted mRNA structures in this region (not shown), but we cannot exclude that these differences play a role.

Another potential cause for slow translation is the presence of rare codons, in particular in the 5' region of the gene [10]. In their recent landmark study on RNA polymerase backtracking [34], Proshkin et al. showed that rare codons not only reduce the speed of translation but also the speed of transcription. Over the entire length of the genes, the two lacLM genes used in this study have a similar number of rare codons, but the number of unfavorable codons among the first 50 triplets is considerably higher in lacLMAci (seven) than in the better expressed lacLMReu (four). As a first step towards investigating the role of rare codons, we replaced two of rare codons the lacLMAci by the corresponding less rare codons occurring in the better expressed lacLMReu gene. These exchanges included the very rare AGA for arginine in the $15^{\text {th }}$ triplet (frequency $4 \%$ ) which was replaced by CGC (frequency $21 \%$; note that Arg is a six-fold degenerate amino acid). The mutations indeed yielded an increase in $\beta$-galactosidase activity, but the increase was only in the order $25 \%$, and thus far off the approximately 60 -fold increase observed when going from lacLMAci to lacLMReu. While the small increase appears to corroborate our codon-related deliberations in principle, our data seem to indicate that the presence of a few extra rare codons is not sufficient to explain the lower transcription efficiency and/or stability of the lacLMAci transcript.

\section{Conclusion}

The results clearly indicate that the much higher $\beta$ galactosidase levels obtained in L. plantarum harboring lacLM from $L$. reuteri (on pEH9R) as compared to $L$. plantarum harboring lacLM from L. acidophilus (on 
pEH9A) are caused by higher mRNA levels in the former strain. This is remarkable, since the two operons are expressed using identical transcription and translation machineries and start sequences. This shows the importance of translational effects on mRNA levels. Our data so far indicate that these translational effects are caused by subtle sequence variations at the level of (probably several) rare codons or by minor variations in the secondary structure of the TIR, each of which would affect both mRNA synthesis rates and mRNA stability.

\section{Acknowledgements}

The study was supported by the Austrian Forschungsförderungsgesellschaft FFG (K+ Programme) and the Austrian Academic Exchange Service ÖAD (Technology Grant scholarship for T-TN).

\section{Author details}

${ }^{1}$ Food Biotechnology Lab, Department of Food Sciences and Technology, University of Natural Resources and Life Sciences Vienna, Austria. ${ }^{2}$ Research Centre Applied Biocatalysis, Graz, Austria. ${ }^{3}$ Department of Chemistry, Biotechnology and Food Science, Norwegian University of Life Sciences, Ås, Norway. ${ }^{4}$ School of Biotechnology and Food Technology, Hanoi University of Science and Technology (HUST), Hanoi, Vietnam.

\section{Authors' contributions}

T-TN, TH-N, TM and GM designed the experiments, T-TN, TM and PS performed the cultivations and quantifications, DH and VGHE conceived of the study, T-TN drafted the manuscript, GM and VGHE contributed to the discussion, CKP supervised research and wrote the final version of the paper. All authors read and approved the final manuscript.

\section{Competing interests}

The authors declare that they have no competing interests.

Received: 26 August 2010 Accepted: 22 June 2011

Published: 22 June 2011

\section{References}

1. de Vos WM: Safe and sustainable systems for food - grade fermentations by genetically modified lactic acid bacteria. International Dairy Journal 1999, 9:3-10.

2. de Vos WM: Gene expression systems for lactic acid bacteria. Ecology and industrial microbiology; Current Opinion in Microbiology 1999, 2:289-295.

3. Kuipers OP, de Ruyter PG, Kleerebezem M, de Vos WM: Controlled overproduction of proteins by lactic acid bacteria. Trends Biotechnol 1997, 15(4):135-140.

4. Pouwels PH, Leer RJ: Genetics of lactobacilli: plasmids and gene expression. Antonie Van Leeuwenhoek 1993, 64(2):85-107.

5. Mierau I, Kleerebezem M: 10 years of the nisin-controlled gene expression system (NICE) in Lactococcus lactis. Appl Microbiol Biotechnol 2005, 68(6):705-717.

6. Sorvig E, Gronqvist S, Naterstad K, Mathiesen G, Eijsink VGH, Axelsson L: Construction of vectors for inducible gene expression in Lactobacillus sakei and L. plantarum. FEMS Microbiol Lett 2003, 229(1):119-126.

7. Axelsson $L$, Holck A: The genes involved in production of and immunity to sakacin A, a bacteriocin from Lactobacillus sake Lb706. J Bacteriol 1995, 177(8):2125-2137.

8. Brurberg MB, Nes IF, Eijsink VGH: Pheromone-induced production of antimicrobial peptides in Lactobacillus. Mol Microbiol 1997, 26(2):347-360.

9. Huhne $K$, Axelsson L, Holck A, Krockel L: Analysis of the sakacin P gene cluster from Lactobacillus sake Lb674 and its expression in sakacinnegative Lb. sake strains. Microbiology 1996, 142(Pt 6):1437-1448.

10. Halbmayr E, Mathiesen G, Nguyen TH, Maischberger T, Peterbauer CK Eijsink VGH, Haltrich D: High-level expression of recombinant betagalactosidases in Lactobacillus plantarum and Lactobacillus sakei using a Sakacin P-based expression system. J Agric Food Chem 2008, 56(12):4710-4719.
11. Sorvig E, Mathiesen G, Naterstad K, Eijsink VGH, Axelsson L: High-level, inducible gene expression in Lactobacillus sakei and Lactobacillus plantarum using versatile expression vectors. Microbiology 2005, 151(Pt 7):2439-2449.

12. Nakayama T, Amachi T: Beta-galactosidase, Enzymology. In Encyclopedia of Bioprocess Technology: Fermentation, Biocatalysis, and Bioseparation. Edited by: Flickinger MC, Drew SW. John Willey: New York; 1999:1291-1305.

13. Nguyen TH, Splechtna B, Steinbock M, Kneifel W, Lettner HP, Kulbe KD, Haltrich D: Purification and characterization of two novel betagalactosidases from Lactobacillus reuteri. J Agric Food Chem 2006, 54(14):4989-4998.

14. Splechtna B, Nguyen TH, Zehetner R, Lettner HP, Lorenz W, Haltrich D: Process development for the production of prebiotic galactooligosaccharides from lactose using beta-galactosidase from Lactobacillus sp. Biotechnol J 2007, 2(4):480-485.

15. Sani RK, Chakraborti S, Sobti RC, Patnaik PR, Banerjee UC: Characterization and some reaction-engineering aspects of thermostable extracellular beta-galactosidase from a new Bacillus species. Folia Microbiol (Praha) 1999, 44(4):367-371.

16. Nguyen TH, Splechtna B, Krasteva S, Kneifel W, Kulbe KD, Divne C, Haltrich D: Characterization and molecular cloning of a heterodimeric beta-galactosidase from the probiotic strain Lactobacillus acidophilus R22. FEMS Microbiol Lett 2007, 269(1):136-144.

17. Splechtna B, Nguyen TH, Steinbock M, Kulbe KD, Lorenz W, Haltrich D: Production of prebiotic galacto-oligosaccharides from lactose using beta-galactosidases from Lactobacillus reuteri. J Agric Food Chem 2006 54(14):4999-5006.

18. Mathiesen G, Huehne K, Kroeckel L, Axelsson L, Eijsink VGH: Characterization of a new bacteriocin operon in sakacin P-producing Lactobacillus sakei, showing strong translational coupling between the bacteriocin and immunity genes. Appl Environ Microbiol 2005, 71(7):3565-3574

19. Kleerebezem M, Boekhorst J, van Kranenburg R, Molenaar D, Kuipers OP, Leer R, Tarchini R, Peters SA, Sandbrink HM, Fiers MW, Stiekema W, Klein Lankhorst RM, Bron PA, Hoffer SM, Nierop Groot MN, Kerkhoven R, de Vries M, Ursing B, de Vos WM, Siezen R: Complete genome sequence of Lactobacillus plantarum WCFS1. Proc Natl Acad Sci USA 2003, 100(4):1990-1995.

20. Eijsink VGH, Brurberg MB, Middelhoven PH, Nes IF: Induction of bacteriocin production in Lactobacillus sake by a secreted peptide. J Bacterio/ 1996, 178(8):2232-2237.

21. Bradford MM: A rapid and sensitive method for the quantitation of microgram quantities of protein utilizing the principle of protein-dye binding. Anal Biochem 1976, 72:248-254.

22. Pushnova EA, Geier M, Zhu YS: An easy and accurate agarose gel assay for quantitation of bacterial plasmid copy numbers. Anal Biochem 2000, 284(1):70-76.

23. Nolan T, Hands RE, Bustin SA: Quantification of mRNA using real-time RTPCR. Nat Protoc 2006, 1(3):1559-1582.

24. Lee $C L, O W$ DS, Oh SK: Quantitative real-time polymerase chain reaction for determination of plasmid copy number in bacteria. $J$ Microbiol Methods 2006, 65(2):258-267.

25. Friehs K: Plasmid copy number and plasmid stability. Adv Biochem Eng Biotechnol 2004, 86:47-82.

26. Skulj M, Okrslar V, Jalen S, Jevsevar S, Slanc P, Strukelj B, Menart V: Improved determination of plasmid copy number using quantitative real-time PCR for monitoring fermentation processes. Microb Cell Fact 2008, 7:6.

27. Livak KJ, Schmittgen TD: Analysis of relative gene expression data using real-time quantitative PCR and the 2(-Delta Delta $C(T))$ Method. Methods 2001, 25(4):402-408.

28. Sorvig E, Skaugen M, Naterstad K, Eijsink VGH, Axelsson L: Plasmid p256 from Lactobacillus plantarum represents a new type of replicon in lactic acid bacteria, and contains a toxin-antitoxin-like plasmid maintenance system. Microbiology 2005, 151(Pt 2):421-431.

29. Kleerebezem M, Beerthuyzen MM, Vaughan EE, de Vos WM, Kuipers OP: Controlled gene expression systems for lactic acid bacteria: transferable nisin-inducible expression cassettes for Lactococcus, Leuconostoc, and Lactobacillus spp. Appl Environ Microbiol 1997, 63(11):4581-4584.

30. Pavan S, Hols P, Delcour J, Geoffroy MC, Grangette C, Kleerebezem M, Mercenier A: Adaptation of the nisin-controlled expression system in 
Lactobacillus plantarum: a tool to study in vivo biological effects. Appl Environ Microbiol 2000, 66(10):4427-4432.

31. Risoen PA, Brurberg MB, Eijsink VGH, Nes IF: Functional analysis of promoters involved in quorum sensing-based regulation of bacteriocin production in Lactobacillus. Mol Microbiol 2000, 37(3):619-628.

32. Richardson JP: Preventing the synthesis of unused transcripts by Rho factor. Cell 1991, 64(6):1047-1049.

33. Roberts JW: Molecular biology. Syntheses that stay together. Science 328(5977):436-437.

34. Proshkin S, Rahmouni AR, Mironov A, Nudler E: Cooperation between translating ribosomes and RNA polymerase in transcription elongation. Science 328(5977):504-508.

35. Deana A, Belasco JG: Lost in translation: the influence of ribosomes on bacterial mRNA decay. Genes Dev 2005, 19(21):2526-2533.

36. Kaberdin VR, Blasi U: Translation initiation and the fate of bacterial mRNAs. FEMS Microbiol Rev 2006, 30(6):967-979.

37. Ganoza MC, Louis BG: Potential secondary structure at the translational start domain of eukaryotic and prokaryotic mRNAs. Biochimie 1994, 76(5):428-439

38. Sorensen MA, Kurland CG, Pedersen S: Codon usage determines translation rate in Escherichia coli. J Mol Biol 1989, 207(2):365-377.

39. Zuker M: Mfold web server for nucleic acid folding and hybridization prediction. Nucleic Acids Res 2003, 31(13):3406-3415.

doi:10.1186/1475-2859-10-46

Cite this article as: Nguyen et al:: Quantitative transcript analysis of the inducible expression system pSIP: comparison of the overexpression of Lactobacillus spp. $\beta$-galactosidases in Lactobacillus plantarum. Microbial Cell Factories 2011 10:46.

\section{Submit your next manuscript to BioMed Central and take full advantage of:}

- Convenient online submission

- Thorough peer review

- No space constraints or color figure charges

- Immediate publication on acceptance

- Inclusion in PubMed, CAS, Scopus and Google Scholar

- Research which is freely available for redistribution

Submit your manuscript at www.biomedcentral.com/submit 